\title{
ÖSSZEKAPCSOLT, AXIÁLIS IRÁNYBAN MOZGÓ SZÁL HÁLÓZATOK MEREVSÉGÉNEK JELLEMZÉSE GRÁFOKKAL
}

\author{
NAGY KEM GYULA
}

\begin{abstract}
Szálakat tartalmazó hálózatok kinematikai jellemzése hozzájárul bizonyos szerves és szervetlen struktúrák, mint a cellulóz nanoszálakat tartalmazó növényi szervek, vagy a kollagén szálakat, illetve ezek kötegeit tartalmazó csontok, különböző szálerősített kompozit anyagok tulajdonságainak mélyebb megértéséhez. E dolgozatban a szálakat olyan egyenes szakaszoknak tekintjük, amelyek csak a szakasz egyenese mentén mozdulhatnak el. A szálak összeköttetéseit rudakkal biztosítjuk, ezek a távolság kényszerek tovább korlátozzák a szálak elmozdulását. Eltekintve a szálak és a rudak alkotta hálózat merevtestszerü mozgásaitól a szálhálózat merevségi gráfjának tulajdonságaival jellemezzük a struktúra infinitezimális merevséget. Szükséges és elégséges feltételt adunk a rudakkal összekapcsolt szálak hálózatának merevségére.
\end{abstract}

\section{Bevezetés}

Szálakat tartalmazó hálózatok kutatása felgyorsult, amióta ismert, hogy ezek nagy szerepet játszanak az élő szervezetekben, szövetekben, ill. sejtekben a mechanikai jelek és azokra adott válaszok transzportjában. A szálakat tartalmazó biológiai vagy egyéb, szintén szálakkal merevített hálózatokban a többszörös kapcsolatok felelősek a teljes struktúra vagy egyes részeinek merevségéért [25], [24], [6], [10]. A biológiai szálakhoz kapcsolódó hatalmas irodalomból csak néhányat említünk meg: cellulóz nanoszálak [2], [20], [19]; kollagén szálak kötegei [4], [15]; a bogarak merev vázát alkotó kitin hálózatok [9]. A sejtjeinkben megtalálható aktin szálak, és az ezeket összekapcsoló fehérje szálak [13]; szintén a sejtekben található mikrotubulusok, és az ezeket összekapcsoló gyengébb fehérje szálak [1].

A fenti hierarchikus struktúrák maguk is többnyire szálas szerkezetűek: az alacsonyabb szinteken a szálak kötegekbe rendeződnek, és ezek a kötegek alkotnak vastagabb szálakat. E szálak és a közöttük levő összekapcsoló elemek esetében az a feltétel, hogy merev szakaszként tekintsük ezeket, erősnek tünhet. Az említett szálak, illetve azok kötegei legtöbb esetben hasonló vagy jobb anyagtulajdonságokkal rendelkeznek, mind a megnyúlás, összenyomás, mind a hajlíthatóság tekintetében, 
mint egy fenyőfából készített hurkapálca, ld. 1. (a) ábra. A kék (nagyobb, sötétebb) tartományok a növényi cellulóz szálakat tartalmazó struktúrákat jelenítik meg (pl. fás szárú növények), míg a sárga (nagyobb, világosabb) tartományok az állati, emberi kollagén szálakat tartalmazó szövetekhez, szervekhez tartoznak (pl. csontok, ín, bőr) a rugalmassági modulus-sürüség koordinátarendszerben ábrázolva (mindkét skála logaritmikus). A kék (nagyobb, sötétebb) tartományon belüli legfelső zöld (világosabb) tartományban a cellulóz nanofibrillek CNF-rugalmassági modulusa meghaladja az acélét, ez szintén alátámasztja modellünk azon feltevését, hogy e szálakat tekintjük merev rudaknak. A szálakat összekötő rudak általában gyengébb anyagszerkezeti tulajdonságokkal rendelkeznek, mint maguk a szálak, e modellben azonban ezeket is rudaknak tekintjük.

\section{Szálszerkezetetek matematikai modelljei}

A háromdimenziós térben elhelyezkedő szálak sürü elrendezése és a köztük lévő viszkózus közeg miatt csak axiális irányban történő elmozdulásokat tekintünk. Tehát a lehetséges elmozdulások a szál irányvektorának, $\overrightarrow{v_{i}}$-nek konstansszorosai lehetnek, $x_{i} \cdot \overrightarrow{v_{i}}$, ahol $\cdot$ a vektor skalárral történő szorzását jelöli, ezt az 1. (b) ábrán szemléltetjük a sötét nyilakkal. Minden szálnak van egy saját pályája tehát a térben, amely egy rögzített egyenes, ennek mentén a szál egyéb kényszerek hiányában tud mindkét irányban mozogni.

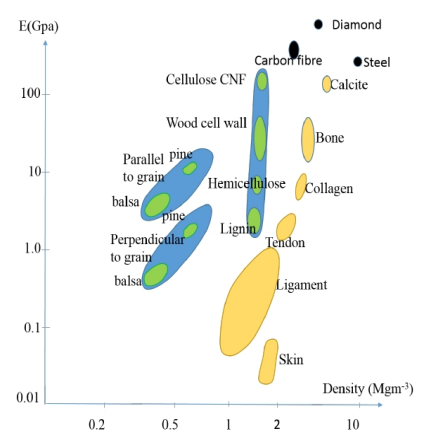

(a) Cellulóz, illetve kollagén szálakat tartalmazó anyagok növények, szervek, szövetek sürüség-rugalmassági modulus grafikonja.

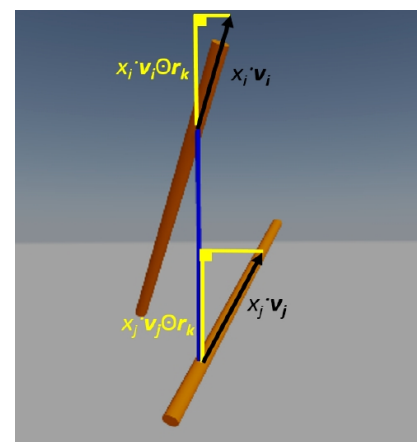

(b) Két szál lehetséges infinitezimális elmozdulása esetén az elmozdulás vektoroknak az összekötő rúdra (az ábrán függőleges) eső vetületei egyenlők, ha deformálhatatlan elemeket feltételezünk.

1. ábra. A valódi szálak lényeges fizikai tulajdonságai és a matematikai modell által feltételezett deformálhatatlanság szemléltetése. 


\subsection{Egyetlen rúddal összekötött két szál mozgásai}

Amennyiben két szálat ideális (deformálhatatlan) rúd (amelyet szintén szakasznak tekinthetünk) kapcsol össze úgy, hogy a rudat a szálhoz egy bármely irányú elfordulást megengedő (gömb-) csukló kapcsolja, akkor a rúd merevségének következtében az egyes szálak elmozdulásvektorainak az összekötő rúd egyenesére eső merőleges vetületei egyenlők kell legyenek.

Azért állítottuk a két szálat és az összekötő rúdjukat olyan helyzetbe az 1. (b) ábrán, hogy valódi méretben lássuk a szálak elmozdulásvektorainak vetületeit az összekötő rúdon. Ha térbelinek tekintjük az ábrát, akkor a rudak infinitezimális elmozdulásának vektorai nem valódi méretükben látszanak, ha azonban síkbelinek tekintjük az ábrát, akkor az infinitezimális elmozdulásvektorok valódi méretükben és irányukban látszanak. Mindkét esetben igaz lesz a következő, ha a két szál mindegyike a saját egyenese mentén úgy mozdulna el, hogy az infinitezimális elmozdulásvektoraik összekötő rúdjukra eső merőleges vetülete nem egyezne meg irány és nagyság szerint is, akkor az összekötő rúd hossza megváltozna, ez azonban ellentmond annak a feltételnek, hogy szálaink, rúdjaink és csuklóink ideálisak. Tehát, ha az összekötő rúd végpontjai által meghatározott vektort $r_{k}$-val jelöljük, az alábbi feltételt kapjuk:

$$
x_{i} \cdot \overrightarrow{v_{i}} \odot \overrightarrow{r_{k}}=x_{j} \cdot \overrightarrow{v_{j}} \odot \overrightarrow{r_{k}},
$$

ahol a $\odot$ jel a két vektor skaláris szorzatát jelenti. Ha bármely két szálat összekötő rúd merőleges az egyik szálra, akkor a szálszerkezetet degeneráltnak hívjuk.

Amennyiben a két szálat összekötő rúd merőleges valamelyik, de csak az egyik szálra, akkor a másik szálnak nem lehetséges nullától különböző elmozdulása. Ha mindketten merőlegesek a rúdra, akkor mindkét szálnak lehet nem nulla infinitezimális elmozdulása, hiszen ekkor $x_{i}$ és $x_{j}$ bármekkora lehet, mivel az (1) egyenlet mindkét oldala nulla. Mivel olyan szerkezeteket keresünk, amelyek infinitezimális elmozdulásokkal sem rendelkeznek, ezért a fenti eseteket kizárjuk azzal, hogy ezután nem degenerált szerkezeteket vizsgálunk. A későbbi merevségi tétel megértéséhez a következő rész nem szükséges, a lehetséges valós (nem az infinitezimális) mozgások megértéséhez igen.

\subsection{Egyetlen rúddal összekötött két szál valós mozgásai}

A két szálat összekötő rúd mozgását szemléltetjük a 2. ábrán, mivel a szálak az egyeneseik mentén mozognak, így nehéz szemléltetni lehetséges helyzeteiket, jobban el tudjuk képzelni a teljes mozgást, ha a két szál összekötő rúdjának helyzeteit mutatjuk meg. Adott, egyetlen rúddal összekapcsolt két szál (nem degenerált) esetén az (1) egyenletnek végtelen sok megoldása lesz. Az ezekhez tartozó mozgó rúd diszkrét helyzeteit szemlélteti a 2. ábra két különböző nézetben. Az összekötő rúd (fekete ferde vonalak), felező és egyik negyedelő pontjának néhány lehetséges 
helyzetét is jelöltük. A rúd felező pontja (fekete pontok) és egyik negyedelő pontja (narancssárga pontok) által leírt alakzat rendre kör (ha a szálak merőlegesek voltak), illetve ellipszis, amelyek valódi méreteikben látszanak a 2. (a) ábrán. Egy tetszőleges másik irányból vett vetületet (nézetet) látunk a 2. (b) ábrán. Ha az alsó szál és a kapcsolódó csuklója (kék pont) egyenes vonalú egyenletes mozgást végez, tehát $x_{i}$ lineárisan változik, akkor az összekötő rúd másik csuklójának helyzete, $x_{j}$ rezgőmozgásszerüen változik, erre a megfelelő végpontok elhelyezkedéséből következthetünk. Eközben az összekötő rúd bármely kijelölt fixpontja ellipszispályát ír le.

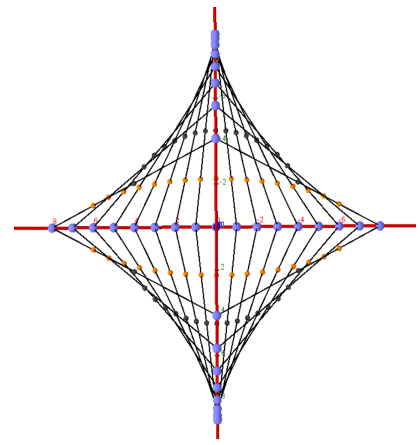

(a) Mindkét szállal párhuzamos síkra vonatkozó vetület (z tengely irányából nézve).

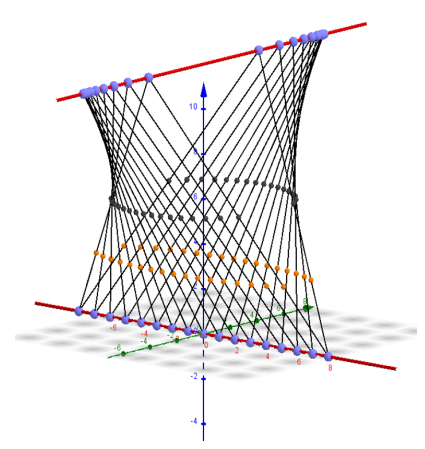

(b) A rúd felező pontja és negyedelő pontjai által leírt kör, illetve ellipszis egy tetszőleges nézetben

2. ábra. Két szálat összekötő rúd lehetséges helyzetei, ill. a rúd végpontjai a megfelelő szálakon, és rendre egy körön és ellipszisen mozgó felezőpontja és negyedelő pontja.

A pályagörbék alakjának igazolása a szálak merőlegessége esetén, és a felezőpontra szorítkozva a KöMaL 2006-os áprilisi számának B. 3906. feladata megoldásaként olvasható [14]. A rúd egyéb fixpontjának, azaz az a:b arányú osztópontjának pályája e feladat megoldásának segítségével hasonlóan meghatározható. A szálak (egyenesek) $a+b$ távolsága és az $A B$ szakasz $d$ hossza között fennáll, hogy $0<a+b<d$. Ekkor vegyünk fel úgy egy derékszögü koordinátarendszert, hogy az $A$ pontot tartalmazó egyenes pontjait az $y=0, z=a$ síkok, a $B$ pontot tartalmazó egyenes pontjait pedig az $x=0, z=-b$ síkok egyenletei, mint egy-egy egyenletrendszer megoldásai adják. Így az $A B$ szakasz $a: b$ arányú osztópontja az $x, y$ síkban helyezkedik el, és egyenlete:

$$
\frac{x^{2}}{b^{2}\left(\frac{d^{2}}{(a+b)^{2}}-1\right)}+x \frac{x^{2}}{a^{2}\left(\frac{d^{2}}{(a+b)^{2}}-1\right)}=1 .
$$

Nem derékszögű szálak esetén a rúd felezőpontja ellipszist ír le, ahogy ezt a 
(3) egyenlet mutatja, ahol a szálak távolsága $2 d$, a rúd hossza $2 l$, és a szálak által bezárt szög felének tangense $c$ :

$$
\frac{x^{2}}{c^{2}\left(l^{2}-b d^{2}\right)}+\frac{x^{2}}{\frac{c^{2}}{l^{2}-b^{2}}-1}=1 .
$$

A nem derékszögű szálak esetében a rúd egyéb pontjának pontos pályaleírásától eltekintünk, mivel az ellipszisek fötengelyeinek irányai az osztóponthoz tartozó arány függvényében változnak, még inkább azért, mert e bekezdés az összekötő rúd teljes mozgását szemléltette, mi pedig infinitezimális elmozdulásokat vizsgálunk, így a fenti megállapításoknak a továbbiakban nem lesz szerepe. Azért vizsgáljuk az infinitezimális elmozdulásokat a merevség szempontjából, mert ezen elmozdulások hiányában szerkezeteink infinitezimálisan merevnek tekinthetők, valamint mert ha már ezeket az elmozdulásokat sem engedik meg a kényszerek, akkor természetesen valós mozgások sem lehetségesek.

\subsection{Több rúddal összekötött szálak lehetséges mozgásai}

Ha legalább két rúd kapcsolja egymáshoz a szálakat (akár két szálnál többet is), akkor a lehetséges mozgásokat egy, az (1) egyenlethez hasonló egyenletekből álló egyenletrendszer megoldásai írják le. Ebben az $x_{i}$ ismeretlenek az egyes szálak lehetséges (infinitezimális) elmozdulásai, az egyenletek pedig az egyes rudakhoz tartozó kényszereket fejeznek ki. Az egyes rudak végpontjai által meghatározott vektorokat $\overrightarrow{r_{k}}$-val jelölve egy 3 szálból és 3 rúdból álló rendszerhez tartozó egyenletrendszer a következő:

$$
\begin{array}{rlrl}
\overrightarrow{v_{1}} \odot \overrightarrow{r_{1}} \cdot x_{1}-\overrightarrow{v_{2}} \odot \overrightarrow{r_{1}} \cdot x_{2} & & =0 \\
\overrightarrow{v_{1}} \odot \overrightarrow{r_{2}} \cdot x_{1} & & -\overrightarrow{v_{3}} \odot \overrightarrow{r_{2}} \cdot x_{3} & =0 \\
& \overrightarrow{v_{2}} \odot \overrightarrow{r_{3}} \cdot x_{2} & -\overrightarrow{v_{3}} \odot \overrightarrow{r_{3}} \cdot x_{3} & =0
\end{array}
$$

A fenti egyenletrendszer $x_{i}$ megoldásai határozzák meg a szerkezet szálaihoz tartozó lehetséges $x_{i} \cdot \overrightarrow{v_{i}}$ elmozdulásvektorokat. A párhuzamos szálak esetét és a jelen cikkben tárgyalt általános esetet (nem ilyen részletességgel) a [17] dolgozat tárgyalja. Általános helyzetű szálakból és rudakból álló rendszer akkor lesz infinitezimálisan merev, ha a fentihez hasonló egyenletrendszernek csak az $x=\overrightarrow{0}$ vektor a megoldása. Az egyenletrendszer együtthatóit a szálak és merevítő rúdjaik térbeli helyzete határozza meg. Előfordulhat, hogy két nem lényegesen különböző konfigurációt tekintve egyiknek létezik, míg a másiknak nem létezik infinitezimális elmozdulása.

\subsubsection{Két rúdal összekapcsolt két szál infinitezimális mozgásai}

Pédaképpen legyenek az $A B C D$ szabályos tetraéder $A B$ és $C D$ egyenesein a szálak úgy, hogy a szálak végpontoktól mért túlnyúlása legyen azonos, rúdjai pedig $A C$ és $B D$ 3. ábra bal oldali szerkezete. 


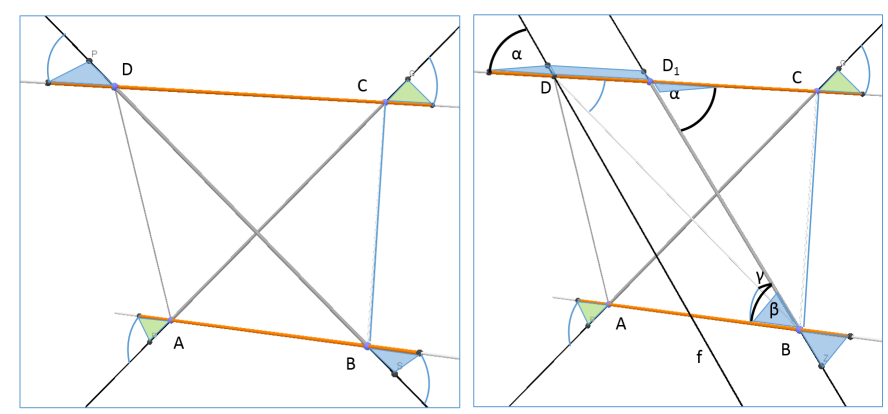

3. ábra. Balra egy infinitezimálisan nem merev, míg jobbra egy infinitezimálisan merev két szálból és két rúdból álló szerkezet látható.

Igazoljuk, hogy ez a szerkezet infinitezimálisan flexibilis (nem merev), vagyis van nem nullától különböző infinitezimális elmozdulása. Tekintsük a $D C$ egyenesen mozgó szál egy infinitezimális elmozdulását a jobb oldali végpontjától a $\mathrm{C}$ pontig, ekkor a D pont a szál bal oldali végpontjáig mozdulna. Ekkor az AB szál A csuklója a szál bal oldali végpontjába mozdulna el, így a rudakon az elmozdulások vetületei mind egyenlök lennének, hiszen azok a lehetséges elmozdulások $\cos \frac{\pi}{3}=\frac{1}{2}$-szorosai. Az ábrán a vékony ívekkel jelölt szögek mindegyike $\frac{\pi}{3}$.

Ha a $B D$ rúd $D$ végpontját áthelyezzük a $D C$ szál $D_{1}$-el jelölt, $D$-hez közelebbi harmadoló pontjába, akkor ilyen infinitezimális elmozdulás nincs, vagyis a rendszer infinitezimálisan is merev lesz. Ekkor az $A C$ rúdra és a $B D_{1}$ rúdra egyidejüleg nem teljesülhet az (1). Tegyük fel, hogy mindkét rúdra teljesülne (1), akkor az előbbi elmozdulásokat tekintve $\cos \alpha=\cos \beta$ teljesülne. Ezért, mivel mindkettő hegyesszög, azt kapnánk, hogy $\alpha=\beta$, de ez nem teljesül, mivel $\alpha=\frac{\pi}{3}+\gamma$, azonban $\beta<\frac{\pi}{3}+\gamma$, mivel ezek egy B csúcsú triéder szögei, ezért a gömbháromszögekre vonatkozó háromszög-egyenlötlenség igazolja az $\alpha>\beta$ egyenlőtlenséget. Természetesen pontosan kiszámolható a szögek és koszinuszaik pontos értéke is. Fentihez hasonló indoklással viszont általánosan igazolható az is, ha $D_{1}$ különbözik a $D$ pontól, a $C$ ponttól és a $C D$ szakasz felezőpontjától, akkor infinitezimálisan merev szerkezetet kapunk. Tehát esetünkben mondhatjuk azt, hogy majdnem mindig merev elrendezést kapunk, tehát a generikus tulajdonság is megjelent, ami azt jelenti, hogy néhány eset kivételével két rúddal összekapcsolt két szál infinitezimálisan merev lesz. A következőkben azt vizsgáljuk, hogy a szálak és rudak általános, azaz generikus térbeli helyzete esetén milyen tényezők befolyásolják a merevséget. 


\section{Szálak generikus hálózata}

Az előző fejezet végén található indoklás bonyolultabb hálózat (több szál összekapcsolva több rúddal) esetén általában nehezen kivitelezhető, ezért ilyenkor a (4) egyenletrendszerhez hasonló egyenletrendszert kell vizsgálni. Az oszlopvektorai lineáris függetlenségéhez szükséges, hogy a szálak és a rudak irányvektorainak skaláris szorzatai lineárisan független rendszert alkossanak. Ezeket viszont a rudak végpontjainak koordinátáiból, illetve a szálak végpontjaiból számolhatjuk. Kellően általános, generikus lesz a hálózat, ha a szálak tartópontjainak és a rudak végpontjainak koordinátáiból álló struktúra algebrailag független lesz a racionális test felett, hiszen ekkor nem lesz esetleges az egyenletrendszer oszlopvektorainak függetlensége, azok között algebrai összefüggés nem lehet. A kizárt lehetöségeket 0 , míg a megengedetteket 1 valószínüséggel választhatjuk.

\subsection{Lehetséges előzmények}

Modellünk hasonlít a generikus rúd-csukló szerkezetekhez [16], [22], [12]. A szerzők foglalkoznak a letüzési problémákkal is, amely azt kérdezi, hogy adott szerkezetnek melyik csuklóit kell különböző kényszerekkel „rögzítenünk”, hogy merev szerkezethez jussunk [21], [11]. Bevezethettük volna modellünket úgy, hogy egy rúd-csukló szerkezet néhány rúdját kinevezzük szálnak, és ezek csuklóira írunk elő szál (kinevezés előtt rúd) irányú lineáris kényszereket, hasonlóan a letűzési problémához. A többi rúd pedig továbbra is rúd maradna. Ez a modell azonban több vonatkozásban is különbözne az általunk vizsgálttól. Az említett letűzési probléma esetén a feltételek a csuklókra írnak elő kényszereket, esetünkben pedig a rudakra írjuk elő ezeket. Valószínúleg előbbi elgondolással is megkapható e cikk eredménye, tudtommal nem közöltek ilyen eredményt térben, tehát megválaszolandó nyitott kérdésnek tekinthető.

\subsection{Kapcsolat a mechanizmusokkal és a tensegrity szerkezetekkel}

Bevezethettük volna modellünket a test-rúd (body-bar) struktúrák speciális eseteként úgy is, hogy az egyes test elemeket tekintettük volna szálaknak. Ez egy újabb megválaszolandó kérdés lehet. A mechanizmusok mozgásainak vizsgálata ([5], [7], [8]) már egyetemi szinten is a szabadsági fok megállapításával szokott kezdődni. A Csebisev-Grübler-Kutzbach-kritérium vizsgálata a kiindulópont, az általunk vizsgált probléma tekinthető speciális, nagyon sok elemből álló mechanizmusként, és tételünk tekinthető a mi speciális problémánkra adott olyan válasznak, amely garantálja a mechanizmus szabadsági fokának gyors áttekinthető meghatározását. A mechanizmus alkotóelemei jelen tárgyalásban egydimenziós szakaszok, ezek közül a szálaknak nevezettek két pontja azonos csúszkán mozog, míg a rudaknak nevezettek a végpontjaikban csatlakoznak a szálakhoz. E felfogásból adódóan további problémák vethetők fel, amelyeknek részletes tárgyalásáról a szerzőnek nincs tudomása, így feltehetően további nyitott kérdések is megfogalmazhatók e 
területen. Például körlapok normálisát és középpontját rögzítve a térben, majd ezek kiválasztott pontjait csuklókkal rudak közbeiktatásával egymáshoz rögzítve analóg feladatot kapunk. Szintén nem tárgyalt kérdés, ha a keresztkapcsolatokat létesítő rudak helyett, vagy mellett köteleket, illetve támaszokat is megengedünk, mint lehetséges kényszereket [18], azaz kiterjeszthetö-e Recski és Shai [23] eredménye az általunk vizsgált szál szerkezetekre. Sejthetően igen, hiszen mindkét esetben egydimenziós mozgásokat vizsgálunk. Ez a rész a szerkesztő azon kérésére került a cikkbe, hogy próbáljam magasabb kontextusba helyezni a következő eredményt.

\subsection{Rudakkal összekapcsolt szálakból álló generikus hálózat merevsége}

A 2. fejezet szerint kettő kitérő szál egyetlen összekapcsolt rúddal még nem lesz merev, kettővel összekapcsolva generikus helyzetben már merev lesz.

3.1. Definíció. Legyen $G(v, r)$ a generikus helyzetű szálakból és rudakból álló hálózat gráfja. A gráf pontjai feleljenek meg az egyes szálaknak, a gráf élei pedig feleljenek meg a rudaknak, azaz két pont között akkor van m számú él, ha a megfelelő két szál között $m$ darab rúd van.

Így $G(v, r)$ párhuzamos élekkel is rendelkezhet. Szükséges és elégséges feltételt adunk a generikus helyzetủ szálakból és rudakból álló hálózat merevségére.

3.1. TÉTEL. Generikus szálakból és rudakból álló hálózat akkor és csak akkor infinitezimálisan merev, ha $G(v, r)$ minden komponense tartalmaz kört.

Bizonyítás. Tekintsünk egy komponenst (összefüggő részgráfot), ha nincsen benne kör, akkor a pontoknak megfelelő szálak együtt tudnak mozogni, mivel a szálakhoz és megfelelő rudakhoz tartozó egyenletrendszer-részletnek, amely a (2) egyenletrendszerrel analóg egyenletrendszer megfelelő elemeiből áll, lesz zérustól különböző megoldása, hiszen ez a részegyenletrendszer eggyel kevesebb egyenletből áll, mint a szálak, azaz az ismeretlenek száma. A komponenshez tartozó rudak száma ugyanis eggyel kevesebb, mint a szálaké a körmentesség miatt, így az oszlopvektorok összefüggő rendszert alkotnak. Másik irány: ha a kiválasztott komponens tartalmaz kört, akkor a kör pontjainak megfelelő szálak és az ezeket összekapcsoló rudaknak megfelelő részegyenletrendszer továbbra is homogén és együtthatóvektorai lineárisan függetlenek a generikusság következtében. Egyszerübben: a megfelelő részegyenletrendszerben az ismeretlenek száma nem több, mint az egyenleteké. Így a megoldás csak a zérus vektor lehet, tehát a megfelelő szálak nem mozognak. 

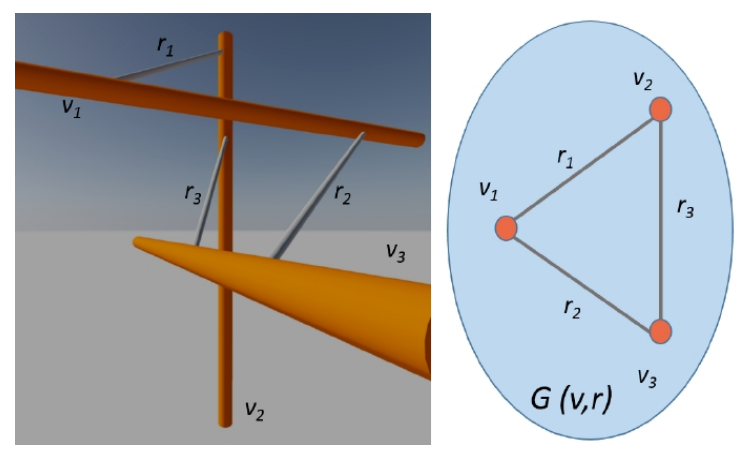

4. ábra. Balra három szál látható páronként összekapcsolva rudakkal, jobbra mellette a szálakból és rudakból álló hálózat $G(v, r)$ gráfja, amely összefüggő, tehát egyetlen komponensből áll, és az tartalmaz kört, ezért a 3.1. tétel következtében a bal oldali hálózat merev, amennyiben generikus.

Példaként hagyjuk el a 4. ábra szerkezetének $r_{1}$ rúdját, úgy a szerkezetnek egy véges mozgása a következő: ha $v_{1}$ balra, akkor $r_{2}$ miatt $v_{3}$ előre, $r_{3}$ miatt $v_{2}$ pedig lefelé mozog. Az $r_{1}$ visszahelyezése esetén $v_{2}$ hasonlóan lefelé mozdulna, generikus esetben ez a két egyirányú elmozdulás különböző nagyságú lenne, ezért nem is jöhet létre, így a generikus szerkezet merev lesz.

3.1. KÖvetKezmény. A fenti tétellel egy gyorsan ellenőrizhető feltételt (összefüggöség, körmentesség) adtunk különböző elasztikus szál struktúrákat modellező szimulációs algoritmusok bemeneti struktúráihoz, ezek általában egy, a fentihez hasonló merev struktúrából indulnak, a szálak és a rudak helyén azonban rugókból és dugattyúkból álló, sorosan és/vagy párhuzamosan illesztett elemek találhatók, így közelítve a konkrét szálak valóságos tulajdonságait [1], [4], [15].

3.2. KövetKezmény. A szálak általában több rúddal kapcsolódnak egymáshoz. Érdemes vizsgálni a szerkezet stabilitása, biztonsága érdekében, mi történik akkor, ha néhány szereplő kiesik, tönkremegy. A gráfok pont- és élösszefüggőségére vonatkozó eredmények [3] jól jellemzik a szálak hálózatának biztonságát, hiszen a szálak szétszakadása esetén a pontösszefüggöség, míg a rudak tönkremenetele esetén az élösszefüggőség lesz hasznos jellemző a további vizsgálatokban.

\section{Köszönetnyilvánítás}

Köszönöm Gerencsér László értékes észrevételeit, amelyek segítették a cikket jobbá tenni. 


\section{Hivatkozások}

[1] Ahmadzadeh, H., Smith, D. H., and Shenoy, V. B.: Viscoelasticity of tau proteins leads to strain rate-dependent breaking of microtubules during axonal stretch injury: predictions from a mathematical model., Biophysical journal, Vol. 106 No. 5, pp. 1123-33 (2014). DOI: 10.1016/j.bpj.2014.01.024

[2] Easterling, K. E., Harrysson, R., Gibson, L. J., and Ashby, M. F.: On the Mechanics of Balsa and Other Woods, Proceedings of the Royal Society of London A: Mathematical, Physical and Engineering Sciences, Vol. 383 No. 1784, pp. 31-41 (1982). DOI: 10.1098/rspa.1982.0118

[3] Frank, A.: Connections in combinatorial optimization, Oxford University Press (2011).

[4] Gautieri, A., Vesentini, S., Redaelli, A., And Buehler, M. J.: Hierarchical structure and nanomechanics of collagen microfibrils from the atomistic scale up, Nano Letters, Vol. 11 No. 2, pp. 757-766 (2011). DOI: 10.1021/nl103943u

[5] Gosselin, C. M. And Angeles, J.: Singularity Analysis of Closed-Loop Kinematic Chains, IEEE Trans. Rob. Autom, Vol. 6 No. 3, pp. 281-290 (1990). DOI: 10.1109/70.56660

[6] Hegyi, D., Sajtos, I., And SÁndor, G.: Long-Term Strain Measuring of Technical Textiles by Photographic Method, Materials Science Forum, Vol. 537-538, pp. 381-388 (2007). DOI: 10.4028/www.scientific.net/MSF.537-538.381

[7] HontobÁgyi, Z.: Numerical analysis of inextensional, kinematically in-determinate assemblies, Periodica Polytechnica Civil Engineering, Vol. 44 No. 1, pp. $43-55$ (2000).

[8] Husty, M. L., Pfurner, M., Schröcker, H. P., and Brunnthaler, K.: Algebraic methods in mechanism analysis and synthesis, Robotica, Vol. 25 No. 6, pp. 661-675 (2007). DOI: $10.1017 /$ S0263574707003530

[9] Ilnicka, A. And Lukaszewicz, J. P.: Discussion Remarks on the Role of Wood and Chitin Constituents during Carbonization, Frontiers in Materials, Vol. 2 No. March, pp. 1-6 (2015). DOI: 10.3389/fmats.2015.00020

[10] Ingber, D. E., Wang, N., And Stamenovic, D.: Tensegrity, cellular biophysics, and the mechanics of living systems., Reports on progress in physics. Physical Society (Great Britain), Vol. 77 No. 4 (2014), 046603. DOI: 10.1088/0034-4885/77/4/046603

[11] Jordán, T.: Rigid and Globally Rigid Graphs with Pinned Vertices Rigid and Globally Rigid Graphs with Pinned Vertices, Egerváry Research Group on Combinatorial Optimization, Vol. 05, 1-18 (2009). DOI: 10.2118/0209-018-TWA

[12] Jordán Tibor; Recski András; Szeszlér Dávid: Rendszeroptimalizálás, Typotex (2004).

[13] Karsai, Á., Mártonfalvi, Z., Nagy, A., Grama, L., Penke, B., and Kellermayer, M.: Mechanical manipulation of Alzheimer's amyloid $\beta 1$-42 fibrils, Journal of Structural Biology, Vol. 155 No. 2, pp. 316-326 (2006). DOI: 10.1016/j.jsb.2005.12.015

[14] KömaL: B.3906 matematika feladat, Középiskolai Matematikai és Fizikai Lapok, Vol. 56 No. 4 (2006).

[15] Licup, A. J., Sharma, A., And MacKintosh, F. C.: Elastic regimes of subisostatic athermal fiber networks, Physical Review E, Vol. 93 No. 1 (2016).

[16] Lovász, L. And Yemini, Y.: On Generic Rigidity in the Plane, SIAM. J. on Algebraic and Discrete Methods, Vol. 3 No. 1, pp. 91-98 (1982). DOI: 10.1137/0603009 
[17] Nagy Kem, G.: Flexibility and rigidity of cross-linked Straight Fibrils under axial motion constraints, Journal of the Mechanical Behavior of Biomedical Materials, Vol. 62, pp. 504-514 (2016), DOI: 10.1016/j.jmbbm.2016.05.032

[18] Nagy Kem, G.: Bracing rhombic structure by one-dimensional tensegrities, Meccanica, Vol. 52 No. 6, pp. 1283-1293 (2017). DOI: 10.1007/s11012-016-0477-0

[19] PARK, Y. B. AND Cosgrove, D. J.: A revised architecture of primary cell walls based on biomechanical changes induced by substrate-specific endoglucanases., Plant physiology, Vol. 158 No. 4, pp. 1933-43 (2012). DOI: 10.1104/pp.111.192880

[20] Racz, I. And Borsa, J.: Swelling of carboxymethylated cellulose fibres, Cellulose, Vol. 4 No. 4, pp. 293-303 (1997). DOI: 10.1016/S0008-6215(97)00173-0

[21] Recski, A.: A network theory approach to the rigidity of skeletal structures Part I. Modelling and interconnection, Discrete Applied Mathematics, Vol. 7 No. 3, pp. 313-324 (1984). DOI: 10.1016/0166-218X(84)90007-6

[22] Recski, A.: Matroid Theory and its Applications in Electric Network Theory and in Statics, Algorithms and Combinatorics, Springer Berlin Heidelberg (1989).

[23] Recski, A. And Shai, O.: Tensegrity frameworks in one-dimensional space, European Journal of Combinatorics, Vol. 31 No. 4, pp. 1072-1079 (2010). DOI: 10.1016/j.ejc.2009.09.008

[24] VÄkiparta, M., Yli-Urpo, A., And Vallittu, P. K.: Flexural properties of glass fiber reinforced composite with multiphase biopolymer matrix, Journal of Materials Science: Materials in Medicine, Vol. 15 No. 1, pp. 7-11 (2004). DOI: 10.1023/B:JMSM.0000010091.34422.45

[25] WOOD, G. C. AND KEECH, M. K.: The formation of fibrils from collagen solutions. 1. The effect of experimental conditions: kinetic and electron-microscope studies., The Biochemical Journal, Vol. 75 No. 3, pp. 588-98 (1960). DOI: 10.1042/bj0750588

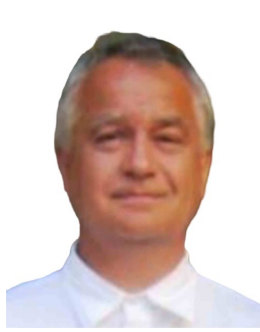

Nagy Gyula (1960) elemi tanulmányait Buzsákon, illetve Fonyódon végezte. 1984-ben matematika, fizika, ábrázoló geometria szakos középiskolai tanári diplomát szerzett az ELTE-n, előtte és utána katonai szolgálatot teljesített. 1984-1997-ig matematikát oktat a Budapesti Szent István Gimnázium speciális matematika tagozatán. 1990-től matematika, ábrázoló geometria, müszaki informatika, AutoCAD oktatást végez a SZIE Ybl Miklós Építéstudományi Karán, kezdetben

főiskolai adjunktusként, jelenleg főiskolai tanárként. Időközben két periódusban az Ábrázolás és Számítástechnika Tanszéket vezeti, számos kari adminisztratív feladatot vállalt. Nős, három gyermeke van. Rúd szerkezetek merevségét kutatja a diszkrét matematika és a statika határterületén. Recski András témavezetésével 1998-ban PhD-fokozatot szerez a BME-n. 2001-2015-ig a KöMaL föszerkesztöje. 2016-tól ismét publikál, a strukturális biológia témaköre is érdekli. Közel 60 MTMT-rekordja van közel 40 hivatkozással. 2017-ben habilitált a Pécsi Egyetemen. Biztonságtechnikai mérnök, foglalkozik a problémamegoldó gondolkodás oktatásával. 


\section{NAGY KEM GYULA}

SZIE

Ybl Miklós Építéstudományi Kar

1146 Budapest, Thököly út 74 .

nagy.gyula@ybl.szie.hu

\section{CHARACTERIZATION OF THE CROSS-LINKED FIBRILS UNDER AXIAL MOTION CONSTRAINTS WITH GRAPHS}

\section{Gyula Nagy Kem}

The filament networks play a significant role in biomaterials as structural stability and transmit mechanical signs. Introducing a 3D mechanical model for the infinitesimal motion of crosslinked fibrils under axial motion constraints, we provide a graph theoretical model and give the characterization of the flexibility and the rigidity of this framework.

The connectedness of the graph $G(v, r)$ of the framework in some cases characterizes the flexibility and rigidity of these structures. In this paper, we focus on the kinematical properties of fibrils and proof the next theorem for generic nets of fibrils that are cross-linked by another type of fibrils. "If the fibrils and the bars are generic positions, the structure will be rigid if and only if each of the components of $G(v, r)$ has at least one circuit." We offer some conclusions, including perspectives and future developments in the frameworks of biostructures as microtubules, collagens, celluloses, actins, other polymer networks, and composite which inspired this work.

Keywords: kinematics, graph connectivity, generic, fibril network, cross-link.

Mathematics Subject Classification (2000): 53A17, 52C25, 05C40. 